\title{
PENGAWASAN MUTU AIR MINUM DALAM KEMASAN DI CV SUMBER TIRTA BERKAH ABADI SLAWI
}

\author{
Nuraedi Rosidah*1, Daryono², Yunika Purwanti ${ }^{3}$ \\ ${ }_{1,2,3}$ Program Studi Ilmu dan Teknologi Pangan Universitas Muhadi Setiabudi Brebes \\ email : yunika@umus.ac.id
}

\begin{abstract}
Abstrak
Air Minum Dalam Kemasan (AMDK) menurut Standar Nasional Indonesia 01-35532015 adalah air baku yang telah diproses,dikemas, dan aman diminum mencangkup air mineral dan air demineral. Air minum dalam kemasan harus memenuhi syarat-syarat standar kualitas air. Syarat tersebut berupa standar fisik, kimia, dan mikrobiologi. Pengawasan mutu penting dilakukan dari penerimaan bahan baku air sampai produk akhir yang siap di pasarkan. Pengawasan pada bahan baku air meliputi penampungan, water treatment, ozonisasi, pengisian dan packing. Faktor utama yang mempengaruhi dalam proses pembuatan air minum dalam kemasan yang dapat menurunkan kualitas adalah tingkat kontaminasi yang sering terjadi seperti kontaminasi udara ruang produksi,dan kontaminasi air. Tujuan penulisan laporan praktikum tentang pengawasan mutu adalah untuk mengetahui cara mempertahankan kualitas air minum dalam kemasan agar sesuai dengan SNI 01-3553-2015. Hasil obeservasi menunjukkan uji laboratorium dan uji fisik bahan penolong yang telah dilakukan CV. Sumber Tirta Berkah Abadi, memenuhi SNI 3553 : 2015.
\end{abstract}

Kata kunci: air minum dalam kemasan, pengawasan mutu,kualitas air, pengolahan air

\section{PENDAHULUAN}

Ilmu dan Teknologi Pangan merupakan salah satu Program Studi Fakultas Sains dan Teknologi Universitas Muhadi Setiabudi Brebes, salah satu mata kuliahnya yakni Ilmu Tekhnologi Pangan yang membahas mengenai proses pengolahan makanan dan minuman dengan penerapan tekhnologi agar sesuai dengan baku mutu SNI dan mata kuliah mikrobiologi. Sesuai mata kuliah yang telah ditempuh, penulis memilih tugas khusus dalam Praktek Kerja Lapangan di CV. Sumber Tirta Berkah Abadi yang merupakan perusahaan yang bergerak dibidang Industri air mineral atau Air Minum Dalam Kemasan (AMDK).

Air Minum Dalam Kemasan (AMDK) menurut Standar Nasional Indonesia 01-35532015 adalah air baku yang telah diproses,dikemas,dan aman diminum mencangkup air mineral dan air demineral. Air minum dalam kemasan harus memenuhi syarat-syarat standar kualitas air. Syarat tersebut berupa standar fisik, kimia, dan mikrobiologi Menurut peraturan mentri perindustrian RI nomor: 96/M-IND/PER/12/2011 pasal 10 ayat 2, yang berbunyi Pengendalian mutu AMDK di pabrik dilakukan oleh perusahaan Industri AMDK untuk menjamin tercapainya mutu sesuai persyaratan SNI yang berlaku. Dan pasal 10 ayat 3 Pengendalian mutu sebagaimana dimaksud pada ayat (2) dilakukan pengujian dilaboratorium perusahaan dengan pemeriksaan terhadap mutu AMDK yang diproduksi setiap hari, yang meliputi parameter : a. Organoleptik (bau, rasa, warna, penampakan); b. pH ; c. Kekeruhan ; d. mikrobiologi (angka lempeng total, bakteri coliform) dan analisis fisik. Air minum dalam kemasan harus memenuhi syarat-syarat standar kualitas air. Syarat tersebut berupa standar fisik, kimia, dan mikrobiologi. Asosiasi Air minum kemasan internasional [1] dalam Bottled water code of practice, dan WHO drinking water guidelines telah menetapkan persyaratan standar yang komprehensi meliputi persyaratan kimia,

Submitted: .... 20xx, Accepted: .... 20xx, Published: Agustus 20xx ISSN: xxxx-Xxxx (online), Website: http://jurnal.umus.ac.id/index.php/jtfp 
fisika dan mirobiologi untuk menjamin kualitas dan kemanan produk AMDK. Syarat Mutu Air Mineral SNI 3553:2015. Maka didalam perusahaan ada bagian yang bertugas mengendalikan kualitas produk yaitu Departemen Quality Control (QC) . Quality control adalah bagian yang sangat penting dalam proses berlangsungnya produksi karena quality control sebagai bagian monitoring untuk menjaga kualitas produk baik dari bahan baku, proses produksi bahkan sampai ke produk akhir. Quality control harus menguji, memeriksa, meneliti, dan menganalisis suatu kualitas produk sehingga produk yang didapat sesuai dengan standar perusahaan dan kelayakan untuk diedarkan. Suatu produk memiliki kualitas apabila sesuai dengan standar kualitas yang telah ditentukan. Standar kualitas meliputi bahan baku, proses produksi dan produk jadi. Standar baku mutu air minum yang harus dipenuhi agar suatu persediaan dapat dinyatakan layak sebagai air minum yaitu parameter fisika, mikrobiologi, dan kimia.

1.1. Parameter Fisik

\subsubsection{Suhu}

Temperatur pada air mempengaruhi secara langsung toksisitas banyak bahan kimia pencemar, pertumbuhan mikroorganisme dan virus. Pengaruh temperatur pada kelarutan tergantung pada efek panas secara keseluruhan pada larutan. Jika panas larutan itu adalah endithermis, maka larutan meningkat dengan meningkatnya temperatur dan jika panas dari larutan exithermis, kelarutan akan turun dengan meningkatnya temperatur, dan jika perubahan panasnya kecil, kelarutan sangat kecil dipengaruhi oleh perubahan temperatur.

Menjaga adanya temperatur air yang sedapat mungkin tidak menguntungkan bagi pertumbuhan mikroorganisme dan virus dalam air. Penyimpanan terhadap standar suhu ini, yakni bila suhu air minum lebih tinggi dari suhu udara jelas tidak akan mengakibatkan tidak tercapainya maksud diatas yaitu akan menurunkan penerimaan masyarakat, meningkatkan toksisitas dan kelarutan bahan-bahan polutan, dan dapat menimbulkan suhu bagi kehidupan mikroorganisme dan virus [2].

\subsubsection{Warna}

Tannin, asam, humus, dan bahan dekomposisi jignin, dianggap sebagai bahan warna yang paling utama. Sebagian besi kadang-kadang berasal dari humus (ferric-humate) dan menghasilkan warna dengan potensi tinggi.

30 Warna yang disebabkan oleh bahan-bahan yang tersuspensi dikatakan sebagai "apparent color", yang disebabkan oleh kentalan organis atau tumbuh-tumbuhan yang merupakan koloidal yang disebut sebagai "true color". Dalam analisis air, penting untuk membedakan antara "apparent color" dengan "true color". Intensitas warna dalam air ini diukur dengan satuan unit warna standar yang dihasilkan oleh $1 \mathrm{mg} /$ liter platina (sebagai K2, PtCl6). Standar yang ditetapkan oleh U.S. Public Health Service untuk intensitas warna dalam air minum adalah 20 NTU dengan skala Pt-co. Standar ini lebih rendah dari standar yang ditetapkan oleh standar internasional dari WHO maupun standar nasional dari Indonesia yang besarnya 5-50 NTU.

\subsubsection{Tidak Berbau dan Rasanya Tawar}

Air yang kualitasnya baik adalah tidak berbau dan memiliki rasa tawar. Bau dan rasa air merupakan dua hal yang mempengaruhi kualitas air. Bau dan rasa dapat dirasakan langsung oleh indra penciuman dan pengecap. Biasanya, bau dan rasa saling berhubungan. Air yang berbau busuk memiliki rasa kurang enak. Dilihat dari segi estetika, Air berbau busuk tidak layak dikonsumsi. Bau busuk merupakan sebuah indikasi bahwa telah atau sedang terjadi proses pembusukan (dekomposisi) bahan-bahan organik oleh mikroorganisme di dalam air. Selain itu, bau dan rasa dapat disebabkan oleh senyawa fenol yang terdapat di dalam air.

1.1.4 Total Solid Terlarut $($ Total Disolved Solid $)=$ TDS

Jumlah solid yang berasal dari material-material terlarut. Solid tersuspensi (Suspended Solid $=$ SS) adalah partikel tersuspensi yang dapat diukur dengan menggunakan kertas saring halus. Selain itu, terdapat juga Seltleable Solid (solid yang dapat diendapkan) adalah jumlah solid yang dapat dipisahkan dari air dengan prosedur standar yaitu perbedaan antara 34 SS dalam 
supernatant dan SS dalam sampel air pengukuran settleable solid biasanya digunakan kerucut imhoff berukuran berukuran 1 liter.

\subsubsection{Kekeruhan}

Kualitas air yang baik adalah jernih dan tidak keruh. Batas maksimal kekeruhan air layak minum menurut PERMENKES RI Nomor 907 Tahun 2002 adalah 5 skala NTU [3]. Kekeruhan air disebabkan oleh partikel-partikel yang tersuspensi di dalam air yang menyebabkan air terlihat keruh, kotor, bahkan berlumpur. Bahan-bahan yang menyebabkan air keruh antara lain tanah liat, pasir, dan lumpur. Air keruh bukan berarti tidak dapat diminum atau berbahaya bagi kesehatan. Namun, dari segi estetika, air keruh tidak layak atau tidak wajar untuk diminum [4].

\subsection{Parameter Mikrobiologi}

Coliform adalah bakteri gram negatif, tidak membentuk spora dan dapat tumbuh dan berkembang pada suhu $37 \mathrm{oC}$. Coliform merupakan kelompok bakteri yang mempunyai karakteristik biokimia dan pertumbuhan yang berhubungan dengan kontaminasi faecal. Namun demikian kehadiran Coliform dalam air minum tidak serta merta berarti adanya kontaminasi faecal, karena Coliform juga terdapat pada air yang tidak terkontaminasi oleh faecal misalnya Klebsilia, Entero bacter, dan Cetro bacter. Adanya Coliform mengindikasikan kebersihan dan integritas sistim distribusi serta potensi terbentuknya biofilm [5]. Peraturan Menteri Perindustrian 96/2011 mensyaratkan pengujian Coliform dilakukan seminggu sekali untuk air baku dan untuk AMDK dilakukan setiap hari [6].

\subsection{Parameter Kimia}

PH menunjukkan derajat keasaman suatu larutan. Air yang baik adalah air yang bersifat netral $(\mathrm{pH}=7)$. Air dengan $\mathrm{pH}$ kurang dari 7 dikatakan air bersifat asam, sedangkan air dengan pH di atas 7 bersifat basa. Menurut PERMENKES RI Nomor 907 Tahun 2002, batas pH minimum dan maksimum air layak minum berkisar 6,5-8,5.

1.4. Proses Produksi

Proses produksi merupakan kumpulan dari sub sistem yang saling berinteraksi dengan tujuan mentransformasi input produksi menjadi input produksi. Input produksi ini dapat berupa bahan baku, mesin, tenaga kerja, modal dan informasi. Sendangkan output produksi merupakan produk yang dihasilkan berikut hasil sampingnya, seperti limbah, informasi, dan sebagainya.

1.5. GMP ( Good Manufacturing Practice)

Good Manufacturing Practices merupakan acuan baku yang harus dilaksanakan oleh suatu produsen penghasil produk makanan. Dasar pertimbangan dibuatnya GMP adalah Keputusan Mentri Kesehatan RI No. 23/MenKes/SK/1978,tertanggal 24 Januari 1978 tentang Pedoman Cara Produksi yang baik untuk makanan. Dan Peraturan Menteri Perindustrian RI Nomor: 75/M-IND/PER/7/2010 Tentang Pedoman Cara Produksi Pangan Olahan yang Baik (Good Manufacturing Practices).

Tujuan dalam penelitian ini adalah untuk mengetahui secara nyata bentuk penerapan mata kuliah Ilmu Tekhnologi Pangan Pangan, Mengetahui proses produksi pengolahan AMDK, Mengetahui metode pelaksanaan pengawasan mutu yang meliputi uji mutu bahan penolong AMDK dan uji laboratorium bahan baku AMDK.

\section{METODE PENELITIAN}

Pengumpulan data untuk pembuatan laporan yakni dengan observasi lapangan untuk data primer dan penggunaan bahan dokumen untuk data sekunder.

Setelah melakukan observasi lapangan diketahuai bahwa proses pembuatan air minum dalam kemasan, harus melalui beberapa tahapan mulai dari analisis fisik bahan penolong yang berupa karton 220, karton $600 \mathrm{ml}$, lid, cup $220 \mathrm{ml}$, botol $600 \mathrm{ml}$, botol $330 \mathrm{ml}$, straw, lakban, seal.

Proses analisis fisik diawali dengan pengukuran, pengecekan, penelitian, menganalisis bahan penolong sehingga produk yang didapat sesuai dengan standar perusahaan dan kelayakan 
untuk diedarkan. Analisis kimia mulai dari air baku, kemudian masuk ketahap water treatment yang berupa rangkaian filter air dimulai dari sand filter, carbon filter 1 dan carbon filter 2, catridge filter $0,05 \%$, catridge filter $0,03 \%$, catridge filter $0,01 \%$, proses ozonisasi, sterilisasi dengan UV dan kemudian menjadi prodak jadi. Setelah menjadi prodak jadi harus dilakukan uji fisika yaitu pengecekan $\mathrm{pH}$, TDS air yang dilakukan setiap hari dan uji Mikrobiologi dengan pengecekan bakteri coliform untuk memastikan bahwa air sudah sesuai dengan standar. Proses mikrobiologi diawali dengan pembuatan ALT (angka lempeng total) awal, penduga coliform (ALT akhir) dan terakhir penegas coliform dengan ketentuan tertentu. Bila jumlah coliform memenuhi persyaratan SNI maka air tersebut lolos quality control.

Metode pelaksanaan pengawasan mutu dilakukan dengan cara sebagai berikut.

\subsection{Penerimaan (receiving)}

Staff receiving berkewajiban untuk menerima memeriksa barang,atau bahan olahan yang datang dan diserahkan oleh pemasok atas pesanan dari bagian pembelian. Selain menerima receiving juga harus mengadakan pengawasan dan ketelitian di saat barang-barang tersebut datang dan diserahkan oleh pemasok. Ppengawasan pada hakikatnya merupakan usaha memberikan petunjuk kepada para pelaksana agar mereka selalu bertindak sesuai dengan rencana Analalisis uji fisik bahan penolong
Alat
: Gelas ukur, Timbangan elektrik, Jangka sorong dan Senter .
Bahan :Cup, Karton.
Langkah kerja uji fisik cup :

1. Menyiapkan alat dan sampel bahan (tiga sampel cup diambil dari tiga kardus yang berbeda ,dengan posisi pengambilan cup bagian atas, bagian tengah,dan bagian bawah).

2. Menimbang masing-masing cup.

3. Mengukur diameter mulut cup (outer cup diameter), diameter leher cup (neck cup diameter), diameter tubuh bawah cup (body bottom cup diameter),dan tinggi cup.

4. Mencatat hasil pengukuran.

5. Menganalisis dan mengamati clarity, dengan cara mengisi air kedalam cup sampel,dan amati hasilnya.

6. Mengamati droptest, dengan cara menjatuhkan kemasan cup yang telah berisi air dari ketinggian lencang tangan, dan amati hasilnya.

7. Mengukur volume, dengan cara memindahkan air yang ada dalam cup sampel kedalam gelas ukur, amati hasilnya.

Langkah kerja uji karton :

1. Menyiapkan alat dan bahan (tiga sampel karton diambil dari tiga ikatan yang berbeda,dengan posisi pengambilan karton bagian atas, bagian tengan, dan bagian bawah ).

2. Mengukur ukuran (panjang,lebar, tinggi), inner dimension, outer dimension karton dengan jangka sorong.

3. Memotong kardus dengan ukuran $10 \times 10 \mathrm{~cm}$.

4. Memisahkan fluth (lapisan) karton yang terdiri dari gramatur luar, tengah dan dalam.

5. Menimbang gramatur luar, tengah,dan dalam.

6. Mencatat hasil dari masing-masing gramatur.

7. Menganalisis serta mengamati bagian flute karton, join/ket,colour,dan model karton.

Analisis Uji Fisika Bahan Baku Air

Alat : PH meter,TDS (total disolvid solid and conductivity) cup

Bahan : Bahan Air baku,air di sand filter,air di carbon filter ,air di carbon filter, air di catridge filter $0,05 \%$.air di catridge filter $0,03 \%$, air di catridge filter $0.01 \%$, air produk jadi di mesin 16 line dan 8 line.

Langkah uji pH meter dan TDS :

1. Mengambil bahan di masing-masing tanki penampungan di mesin 16 line,dan di mesin 8 line dengan volume $40 \mathrm{ml}$.

2. Menghubungkan $\mathrm{pH}$, dan TDS ke masing-masing sampel air.

3. Tekan on untuk menghidupkan $\mathrm{pH}$ meter dan TDS.

4. Mengamati $\mathrm{pH}$ dari masing-masing bahan dan catat hasil $\mathrm{pH}$ dan TDS . 
Analisis Uji Mikrobiologi

Persiaapan Uji Coliform

Langkah kerja :

1. Mensterilkan alat.

2. Mebungkus alat yang digunakan dengan kertas kopi.

3. Memasukam kedalam oven dengan suhu $1500 \mathrm{C}$ selama 15 menit .

Mengangkat dan mengangin-anginkan tanpa membuka kertas kopi pembungkusnya.

Membuat PCA ( Plate Count Agar )

Alat :

1. Neraca analitik.

2. Spatula.

3. Gelas beker.

4. Tabung reaksi.

5. Cawan petri.

6. Autoklaf.

7. Batang pengaduk.

8. Erlenmeyer.

9. Botol reagen.

10.Tabung dirham.

11.Pipet.

Bahan :

1. Alumunium foil.

2. Bubuk media plate count agar.

3. Aquades.

4. Kapas.

Langkah kerja :

1. Menyiapkan alat dan bahan yang telah di sterilkan .

2. Mengambil sampel produk jadi dibotol reagen ,harus tetap dalam keadaan steril.

3. Membuat P1 dengan cara mengambil $1 \mathrm{ml}$ produk jadi ditambahkan $9 \mathrm{ml}$ aquades,taruh ditabung reaksi kemudian tutup dengan kapas.

4. Membuat P2 denga cara mengambil $1 \mathrm{ml}$ dari $\mathrm{P} 1$ kemudian ditambahkan $9 \mathrm{ml}$ aquades, kocok secara homogen.

5. Membuat PCA $(\mathrm{P} 1)=\mathrm{PCA}(\mathrm{P} 1)$ masing-masing ada $2,1 \mathrm{ml}$ dari $\mathrm{P} 1+15 \mathrm{ml}$ PCA.

a. Menimbang 8,75 gr bubuk PCA.

b. Menambahkan aqudes hingga volume $250 \mathrm{ml}$ kemudian dihomogenkan.

c. Erlenmeyer yang telah ditutup dengan kapas dilapisi alumunium foil ikat dengan benang.

d. Media disterilkan dengan autoklaf pada suhu $121^{\circ} \mathrm{C}$ selama 15 menit.

e. Media yang telah disterilkan didinginkan hingga suhu $45^{\circ}-50^{\circ} \mathrm{C}$.

6. Membuat PCA $(\mathrm{P} 2)=\mathrm{PCA}$ masing-masing ada $2,1 \mathrm{ml}$ dari $\mathrm{P} 2+15 \mathrm{ml}$ PCA.

7. Membuat PCA.

8. Mengaduk secara memutar,ditunggu sampai beku dengan posisi terbalik dan diinkubasi selama 24-48 jam dengan suhu $36-37^{0} \mathrm{C}$.

Membuat Penduga Bakteri Coliform

1. Menyiapkan 15 tabung reaksi yang telah disterilkan.

2. Mengambil 5 tabung reaksi untuk masing-masing komposisi LB 0,1 lima tabung reaksi, LB 1 lima tabung reaksi dan LB 2 lima tabung reaksi.

1) $\mathrm{LB} \quad 0,1=$ lima tabung reaksi, isi dengan tabung dirham dengan posisi terbalik,komposisinya : 1 tetes air produk jadi $+10 \mathrm{ml}$ LB 1 .

2) $\mathrm{LB} 1=$ ada lima tabung reaksi, komposisinya : $1 \mathrm{ml}$ air produk jadi $+9 \mathrm{ml} \mathrm{LB} 1$.

3) $\mathrm{LB} 2$ = ada lima tabung reaksi, komposisinya: $5 \mathrm{ml}$ air produk jadi $+5 \mathrm{ml}$ LB 2.

3. Mengocok terbalik,sampai tabung dirham terisi.

4. LB 0,1, LB 1, LB 2 di inkubasi pada suhu 360-370 C selama 24-48 jam.

Pengawasan Mutu Air Minum Dalam Kemasan di CV Sumber Tirta Berkah Abadi Slawi 
5. Mengamati hasilnnya.

6. Jika terbentuk gas diatas 10 tabung positif dilanjutkan ke penegas coliform,jika kurang dari 19 negatif tidak perlu dilanjutkan.

Membuat Penegas Bakteri

Langkah kerja :

1. Menimbang BGLB ( Brilliant Grind Lactous Broth ).

Misalkan ada 10 tabung yang terbentuk gas. Siapkan tabung reaksi.

2. Mengambil 1 ose (1 tetes) dari tabung reaksi sebelumnya di tambah $10 \mathrm{ml}$ BGLB di inkubasi pada suhu $36-37^{\circ} \mathrm{C}$ selama $24-48$ jam.

\section{HASIL DAN PEMBAHASAN}

Standar pengendalian mutu AMDK ditetapkan dalam Permenperin tahun 2011 tentang persyaratan teknis industri AMDK.Pengendalian mutu dilakukan untuk mencapai mutu produk sesuai dengan SNI AMDK.Badan Standarisasi Nasional (BSN) mengeluarkan standar produk air mineral terbaru, yaitu SNI 01-3553-2015.Secara teknis seluruh produk AMDK yang diproduksi 11 industri AMDK harus memenuhi

Pengendalian mutu produk AMDK dilakukan terhadap air baku,air produk, dan bahan penolong kemasan. Pengujian air baku meliputi analisa bakteri coliform satu kali dalam seminggu serta analisa kimia-fisika sekali dalam sebulan. Standar kimia-fisika air baku mengikuti standar kimia-fisika air bersih. Hal ini dikarenakan syarat mutu air baku adalah standar air bersih. Sedangkan standar pengujian air produk adalah uji organoleptik, $\mathrm{pH}$, kekeruhan dan mikrobiologi yang dilakukan setiap hari. CV.Sumber Tirta Berkah Abadi sudah melakukan pengujian rutin $\mathrm{pH}$ dan TDS pada air baku akan tetapi pengujian kekeruhan belum rutin dilakukan karena alat turbidity sedang rusak.. Hasil pengujian air baku ditampilkan pada Lampiran 1. Hasil pengujian terhadap air baku menunjukkan mutu air baku telah memenuhi standar, hanya satu parameter saja yang belum diketahui yaitu tingkat kekeruhan. Sementara untuk air produk pengujian harian hanya dilakukan untuk parameter organoleptik tanpa rekaman, yaitu dengan cara meminum,mencium,mengamati air produk sebelum dikemas. Bila kejernihan dan rasa air produk dirasa normal oleh personel, maka pengemasan dapat dilakukan.CV Sumber Tirta Berkah Abdi memverifikasi mutu produknya melalui pengujian air produk sesuai SNI 01-3553-2015 setiap bulannya.Perbandingan standar pengendalian mutu produk AMDK dan penerapannya di CV .Sumber Tirta Berkah Abadi disajikan pada Tabel 1. Standar Nasional Indonesia (SNI) 01-35532015 (Tabel 1).

Tabel 1.Standar Pengendalian Mutu Produk AMDK dan Praktik di CV. Sumber Tirta Berkah Abadi

\begin{tabular}{ll}
\hline \multicolumn{1}{c}{ Standar pengujian air baku } & \multicolumn{1}{c}{ Praktik } \\
\hline $\begin{array}{l}\text { Satu kali dalam seminggu unuk analisa } \\
\text { bakteri coliform }\end{array}$ & Pengujian dilakukan \\
\hline $\begin{array}{l}\text { Satu kali dalam seminggu untuk } \\
\text { kalibrasi internal pH meter dan TDS }\end{array}$ & Pengujian dilakukan \\
\hline $\begin{array}{l}\text { Dua tahun sekali kalibrasi external pH } \\
\text { dan TDS }\end{array}$ & Pengujian dilakukan \\
\hline $\begin{array}{l}\text { Satu kali dalam 6 bulan untuk analisa } \\
\text { kimia-fisika }\end{array}$ & $\begin{array}{l}\text { Analisa yang diuji yaitu bau,jumlah zat } \\
\text { padat terlarut (TDS), rasa, suhu, dan } \\
\text { warna. Pengujian dilakukan setiap hari }\end{array}$ \\
& $\begin{array}{l}\text { Analisa kimia yang diuji meliputi } \\
\text { pH,pengujian dilakukan setiap hari }\end{array}$ \\
\hline $\begin{array}{l}\text { Organoleptik } \\
\text { Bau,rasa,warna,penampakan,TDS) }\end{array}$ & $\begin{array}{l}\text { suhu, dan wat padat terlarut (TDS), rasa, } \\
\text { setiap hari }\end{array}$ \\
\hline Ph & Pengujian dilakukan setiap hari dilakukan \\
\hline
\end{tabular}

Pengawasan Mutu Air Minum Dalam Kemasan di CV Sumber Tirta Berkah Abadi Slawi (Nuraedi Rosidah) 
Kekeruhan

Mikrobiologi (TPC dan Coliform)

Tidak dilakukan karena alat sedang dalam

keadaan rusak

Pengujian Dilakukan

Pada Tabel 1. CV. Sumber Tirta Berkah Abadi melakukan pengujian bakteri coliform satu minggu sekali,pengujian derajat keasaman $(\mathrm{pH})$ dan jumlah zat padat terlarut (TDS) diuji setiap hari . Ini sesuai dengan Peraturan Menteri Perindustrian 96/2011 mensyaratkan pengujian Coliform dilakukan seminggu sekali untuk air baku .

Hasil Uji Fisik Cup $220 \mathrm{ml}$ Merek A

Berdasarkanhasil pengamatan yang telah dilakukan,terdapat perbedaan yang nyata antara berat cup di kardus 1, kardus 2, dan kardus 3 yaitu 2,5 di posisi atas,2,47 posisi tengah, 2,51 posisi bawah dari kardus 1 . Berat cup kardus 2 di posisi atas 2,51, tengah 2,52, dan bawah 2,50. Berat cup kardus 3 di posisi atas 2,52, tengah 2,45, dan bawah 2,50 .

Tabel 2. HasilUji Cup $220 \mathrm{ml}$ Merek A

\begin{tabular}{|c|c|c|c|c|c|c|c|c|c|c|}
\hline \multirow{3}{*}{$\begin{array}{l}\text { PARAMETER } \\
\text { UJI }\end{array}$} & \multicolumn{3}{|l|}{ STANDAR } & \multirow[t]{2}{*}{ DUS } & \multicolumn{3}{|c|}{ DUS 2} & \multicolumn{3}{|c|}{ DUS 3} \\
\hline & PABRIK & 1 & & & & & & & & \\
\hline & & A & $\mathbf{T}$ & B & A & $\mathbf{T}$ & B & A & $\mathbf{T}$ & B \\
\hline Berat/Pcs (gr) & $2,45 \pm 2,75$ & 2,71 & 2,72 & 2,58 & 2,5 & 2,5 & 2,5 & 2,52 & 2,53 & 2,5 \\
\hline $\begin{array}{l}\text { Tinggi } \\
(\mathrm{mm})\end{array}$ & $\begin{array}{l}93,30 \\
94,10\end{array}$ & 94 & 94 & 94 & 94 & 94 & 94 & 94 & 94,3 & 94 \\
\hline $\begin{array}{l}\text { Diameter mulut } \\
\text { luar cup (mm) }\end{array}$ & $\begin{array}{l}71,50 \\
72,40\end{array}$ & 73 & 73 & 73 & 73 & 73 & 73 & 73 & 73 & 73 \\
\hline $\begin{array}{l}\text { Diameter leher } \\
\text { luar cup }(\mathrm{mm})\end{array}$ & 64,61 & 65 & 65 & 65 & 65 & 65 & 65 & 65 & 65 & 65 \\
\hline Volume & $215-225 \mathrm{ml}$ & 220 & 220 & 220 & 220 & 220 & 220 & 220 & 220 & 220 \\
\hline Drol & Unbroken & UB & UB & UB & UB & UB & UB & UB & UB & UB \\
\hline Warna & Transparent & tp & $\mathrm{Tp}$ & $\mathrm{Tp}$ & $\mathrm{Tp}$ & $\mathrm{Tp}$ & $\mathrm{Tp}$ & $\mathrm{Tp}$ & $\mathrm{Tp}$ & $\mathrm{Tp}$ \\
\hline
\end{tabular}

Keterangan : $\mathrm{A}=$ bagian atas, $\mathrm{T}=$ bagian tengah, $\mathrm{B}=$ bagian bawah

Hasil Uji Cup 220 ML Merek B

Hasil pengukuran menunjukan berat cup bagian A, B, dan C masing - masing 2,71 gr, $2,72 \mathrm{gr}, 2,58 \mathrm{gr}$.Sehingga sesuai dengan standar pabrik yaitu 2,45 $\pm 2,75$. Tinggi cup A, B, C mempunyai hasil yang sama yaitu $94 \mathrm{~mm}$. diameter mulut luar cup masing - masing bagian sama yaitu $73 \mathrm{~mm}$. Diameter leher cup ,volume, droptest, dan warna cup masing - masing bagian yaitu, $65 \mathrm{~mm}, 220 \mathrm{ml}$, unbroken, dan transparant. Sehingga ketiga cup bagian A,B, dan C Lolos control.

\begin{tabular}{lllll} 
& \multicolumn{2}{l}{ Tabel 3. Hasil Uji Cup 220ML Merek B } \\
& STANDAR PABRIK & \multicolumn{2}{c}{ DUS } & \\
\cline { 3 - 5 } PARAMETER UJI & & A & T & B \\
\hline Berat/Pcs $(\mathrm{gr})$ & $2,45 \pm 2,75$ & 2,71 & 2,72 & 2,58 \\
\hline Tinggi cup $(\mathrm{mm})$ & $93,30 \pm 94,10$ & 94 & 94 & 94 \\
\hline Diameter mulut luar cup $(\mathrm{mm})$ & $71,50 \pm 72,40$ & 73 & 73 & 73 \\
\hline Diameter leher luar cup $(\mathrm{mm})$ & 64,61 & 65 & 65 & 65 \\
\hline Volume & $215-225 \mathrm{ml}$ & 220 & 220 & 220 \\
\hline Droptest & Unbroken & UB & UB & UB \\
\hline Warna & Transparant & Tp & Tp & Tp \\
\hline
\end{tabular}


Hasil Uji Karton 220 ml

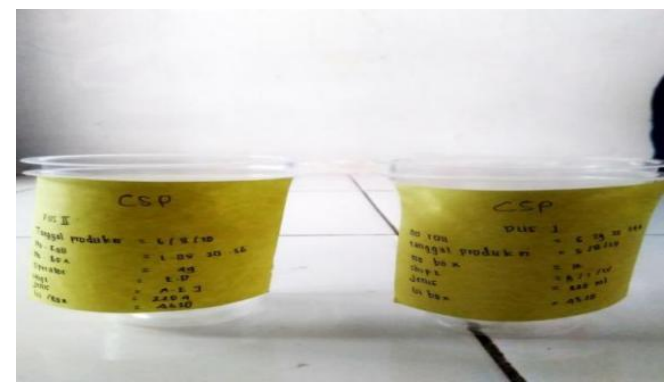

Gambar 4. Cup Sampel $220 \mathrm{~mL}$

Tabel 4. Hasil Uji Karton $220 \mathrm{ml}$

\begin{tabular}{|c|c|c|c|c|}
\hline \multirow{2}{*}{$\begin{array}{l}\text { PARAMET } \\
\text { ER UJI }\end{array}$} & \multirow[t]{2}{*}{ STANDAR PABRIK } & \multicolumn{3}{|c|}{ KARTON 220 ML } \\
\hline & & $\begin{array}{l}\text { KARTON } \\
1\end{array}$ & $\begin{array}{l}\text { KARTON } \\
2\end{array}$ & $\begin{array}{l}\text { KARTON } \\
3\end{array}$ \\
\hline Ukuran pxt & $1171 \times 429 \mathrm{~mm}$ & $\begin{array}{l}1171 \times 429 \\
\mathrm{~mm}\end{array}$ & $\begin{array}{l}1171 \times 429 \\
\mathrm{~mm}\end{array}$ & $\begin{array}{l}1171 \times 429 \\
\mathrm{~mm}\end{array}$ \\
\hline Model & A1 & $\mathrm{A} 2$ & A3 & A4 \\
\hline $\begin{array}{l}\text { Inner } \\
\text { dimension } \\
(\mathrm{mm})\end{array}$ & $335 \times 230 \times 190$ & $\begin{array}{l}335 \times 230 \times 1 \\
91\end{array}$ & $\begin{array}{l}335 \times 230 \times 1 \\
92\end{array}$ & $\begin{array}{l}335 \times 230 \times 1 \\
93\end{array}$ \\
\hline $\begin{array}{l}\text { outer } \\
\text { dimension } \\
(\mathrm{mm})\end{array}$ & $338 \times 233 \times 195$ & $\begin{array}{l}338 \times 233 \times 1 \\
95\end{array}$ & $\begin{array}{l}338 \times 233 \times 1 \\
95\end{array}$ & $\begin{array}{l}338 \times 233 \times 1 \\
95\end{array}$ \\
\hline Substance & $125 \mathrm{BK}-125 \mathrm{MF}-125 \mathrm{BK}$ & $\begin{array}{l}125 \mathrm{BK}- \\
125 \mathrm{MF}- \\
125 \mathrm{BK}\end{array}$ & $\begin{array}{l}125 \mathrm{BK}- \\
125 \mathrm{MF}- \\
125 \mathrm{BK}\end{array}$ & $\begin{array}{l}125 \mathrm{BK}- \\
125 \mathrm{MF}- \\
125 \mathrm{BK}\end{array}$ \\
\hline Flute & $\mathrm{BF}$ & $\mathrm{BF}$ & $\mathrm{BF}$ & $\mathrm{BF}$ \\
\hline Join/ket & $\begin{array}{l}\text { creasing } \\
\text { khusus/glue/stich/lepas/layer/perfo } \\
\text { ration }\end{array}$ & Glue & Glue & Glue \\
\hline Colour & - & $\begin{array}{l}\text { red,light } \\
\text { blue,dark } \\
\text { blue,black }\end{array}$ & $\begin{array}{l}\text { red,light } \\
\text { blue,dark } \\
\text { blue,black }\end{array}$ & $\begin{array}{l}\text { red,light } \\
\text { blue,dark } \\
\text { blue,black }\end{array}$ \\
\hline Condition & Ok & $\mathrm{Ok}$ & $\mathrm{Ok}$ & $\mathrm{Ok}$ \\
\hline
\end{tabular}

Tabel 5.menunjukan perolehan hasil uji mikrobioloigi,pada minggu 1 angka lempeng total dan angka lempeng akhir tidak diketahui karena percobaan gagal,total coliform 14 coloni $/ 250 \mathrm{ml}$. Pada minggu 2 terdapat 6,5 koloni/ml angka lempeng total awal dan 17,5 koloni/ml angka lempeng total akhir,dan terdapat 22 koloni $/ 250 \mathrm{ml}$. SNI 01-3553-2015 persyaratan maksimal untuk angka lempeng total awal di pabrik adalah $1,0 \times 10^{2}$ sedangkan untuk angka lempeng total akhir dipasaraan adalah $1,0 \times 10^{5}$.Sehingga hasil uji mikrobiologi di CV. Sumber Tirta Berkah Abadi memenuhi syarat mutu air mineral.

Tabel 5.Hasil uji mikrobiologi

\begin{tabular}{lll}
\hline \multicolumn{1}{c}{ KRITERIA UJI } & \multicolumn{2}{c}{ PERCOBAAN } \\
\cline { 2 - 3 } & MINGGU 1 & MINGGU 2 \\
\hline Angka lempeng total awal $* *$ & Gagal & $6,5 \mathrm{koloni} / \mathrm{ml}$ \\
\hline Angka lempeng total akhir $* * *$ & Gagal & $17,5 \mathrm{koloni} / \mathrm{ml}$ \\
\hline Coliform & 14 coloni $/ 250 \mathrm{ml}$ & $22 \mathrm{coloni} / 250 \mathrm{ml}$ \\
\hline
\end{tabular}

Pengawasan Mutu Air Minum Dalam Kemasan di CV Sumber Tirta Berkah Abadi Slawi 
Hasil Uji PH dan TDS

Tabel 4.8 Menunjukan hasil pengukuran $\mathrm{pH}$ yang dilakukan pada saat pengambilan sample pada tanggal 08 Agustus 2020 untuk air produk jadi nilai nya 7,4 dan TDS nya 55,sedangkan untuk air baku nilai pH nya 7,4 dan TDS 51. ini berarti air yang ada di CV. Sumber Tirta berkah Abadi memenuhi syarat kesehatan yaitu antara 6,5-8,5 (SNI 3553:2015) (lihat di Tabel 6)

Tabel 6. Hasil Uji PH dan TDS

\begin{tabular}{|c|c|c|c|c|c|c|c|c|c|c|c|c|c|c|c|}
\hline \multirow{3}{*}{$\begin{array}{l}\text { Jenis } \\
\text { sampel }\end{array}$} & \multicolumn{15}{|c|}{ Hasil Pemeriksaan tanggal 08 Agustus 2020} \\
\hline & \multicolumn{5}{|c|}{ Jam : 08.26} & \multicolumn{5}{|c|}{ jam : 11.30} & \multicolumn{5}{|c|}{ jam : 15.25} \\
\hline & $\mathrm{Ph}$ & TDS & Warna & Rasa & Bau & $\mathrm{pH}$ & TDS & Warna & Rasa & Bau & $\mathrm{pH}$ & TDS & Warna & Rasa & $\mathrm{Bau}$ \\
\hline Air Baku & 7,4 & 51 & Tw & $\operatorname{Tr}$ & $\mathrm{Tb}$ & 7,6 & 52 & Tw & $\operatorname{Tr}$ & tb & 7,4 & 54 & Tw & $\operatorname{Tr}$ & tb \\
\hline $\begin{array}{l}\text { Sand } \\
\text { Filter }\end{array}$ & 7,8 & 54 & Tw & $\operatorname{Tr}$ & $\mathrm{Tb}$ & 7,6 & 62 & $\mathrm{Tw}$ & $\mathrm{Tr}$ & $\mathrm{tb}$ & 7,4 & 58 & $\mathrm{Tw}$ & $\mathrm{Tr}$ & tb \\
\hline $\begin{array}{l}\text { Carbon } \\
\text { filter } 1\end{array}$ & 7,4 & 57 & Tw & $\mathrm{Tr}$ & $\mathrm{Tb}$ & 7,4 & 59 & $\mathrm{Tw}$ & $\mathrm{Tr}$ & $\mathrm{tb}$ & 7,4 & 52 & $\mathrm{Tw}$ & $\operatorname{Tr}$ & $\mathrm{tb}$ \\
\hline $\begin{array}{l}\text { Catridge } \\
\text { Filter } \\
0,05\end{array}$ & 7,3 & 52 & Tw & $\mathrm{Tr}$ & $\mathrm{Tb}$ & 7,3 & 52 & $\mathrm{Tw}$ & $\mathrm{Tr}$ & $\mathrm{tb}$ & 7,2 & 52 & $\mathrm{Tw}$ & $\mathrm{Tr}$ & $\mathrm{tb}$ \\
\hline $\begin{array}{l}\text { Produk } \\
\text { Jadi }\end{array}$ & 7,4 & 55 & Tw & $\operatorname{Tr}$ & $\mathrm{Tb}$ & 7,3 & 55 & $\mathrm{Tw}$ & $\mathrm{Tr}$ & $\mathrm{tb}$ & 7,2 & 52 & $\mathrm{Tw}$ & $\mathrm{Tr}$ & tb \\
\hline
\end{tabular}

\section{KESIMPULAN}

Berdasarkan pembahasan tersebut dapat disimpulkan sebagai berikut.

1. Proses produksi air minum dalam kemasan meliputi penampungan bahan baku, dan proses pengolahan air.

2. Pengawasan mutu produk AMDK di CV Sumber Tirta Berkah Abadi dilakukan terhadap air baku,air produk jadi, dan bahan penolong kemasan. Pengujian air baku meliputi analisa bakteri coliform satu kali dalam seminggu, uji $\mathrm{pH}$,warna,bau,rasa dan TDS dilakukan setiap hari

3. Berdasarkan uji laboratorium dan uji fisik bahan penolong yang telah dilakukan CV. Sumber Tirta Berkah Abadi, memenuhi SNI 3553 : 2015. Uji laboratorium yang dilakukan meliputi uji mikrobiologi,uji pH dan TDS , dan uji kimia fisika.

\section{SARAN}

Diperlukan penelitian lebih lanjut mengenai pengawasan mutu air minum dalam kemasan selama penyimpanan di Gudang dan penerapan GMP di ruang produksi hingga ruang penyimpanan.

\section{DAFTAR PUSTAKA}

[1] IBWA, 2015, Bottled water code of practice, Alexandria, Virginia.

[2] Sutrisno Totok, 2004, Teknologi Penyediaan Air Bersih, PT Asti Musatya Jakarta.

[3] Keputusan Mentri Kesehatan RI No. 23/MenKes/SK/1978,tertanggal 24 Januari 1978 tentang Pedoman Cara Produksi yang baik untuk makanan.

[4] Awaluddin.N., 2007, Teknologi Pengolahan Air Tanah Sebagai Sumber Air Minum Pada Skala Rumah Tangga, LEM-FTSP UII, Yogyakarta.

[5] Medema, G.J., Shaw, S., Waite, M., Snozzi, M., Morreau, A., dan Grabouw, W, 2003, Chatchment characterisation and source water quaity in WHO Assessing microbial Safety of drinking water. Iwa Publishing London.

[6] Kemenperin RI Kementerian Perindustrian RI, 2010, Peraturan Menteri Perindustrian RI Nomor 75/M-IND/PER/7/2010 tentang Pedoman Cara Produksi Pangan Olahan yang Baik (Good Manufacturing Practices), Jakarta (ID): Kemenperin RI. 